\title{
Balance y perspectivas del Registro de Paisajes de Interés Cultural de Andalucía
}

Silvia Fernández Cacho | Instituto Andaluz del Patrimonio Histórico Víctor Fernández Salinas | Universidad de Sevilla José María Rodrigo Cámara, José Manuel Díaz Iglesias, Isabel Durán Salado, Isabel Santana Falcón, Jesús Cuevas García | Instituto Andaluz del Patrimonio Histórico Beatriz González Sancho, Esther López Martín | colaboradoras del IAPH

URL de la contribución <www.iaph.es/revistaph/index.php/revistaph/article/view/3667>

\section{RESUMEN}

El Convenio Europeo del Paisaje (Consejo de Europa, 2000), en vigor en España desde el 1 de marzo de 2008, detalla en su capítulo II ('Medidas nacionales') una serie de obligaciones para los distintos estados firmantes entre las que relacionan (art. 6) la identificación y cualificación de paisajes, mediante el análisis de sus características (caracterización) y la consideración de los valores particulares que les atribuyen las Partes y la población interesadas (en nuestro caso, sus valores como patrimonio cultural).

El Registro de Paisajes de Interés Cultural de Andalucía (R-PICA) es un cuerpo de datos homogéneo y normalizado que recoge una completa y diversa información sobre áreas territoriales que han sido seleccionadas por ser depositarias de valores patrimoniales, culturales e históricos, que han participado y son testigos actuales de su formación como un paisaje cultural reconocible y significativo de Andalucía.

Con la primera caracterización de cobertura regional de una selección de paisajes culturales, más de 100 por el momento, se habrá consolidado una metodología innovadora con la que se consigue la integración de diferentes fuentes de información y disciplinas científicas.

\section{Palabras clave}

Andalucía | Paisaje cultural | Patrimonio cultural | Registro de Paisajes de Interés Cultural de Andalucía | 


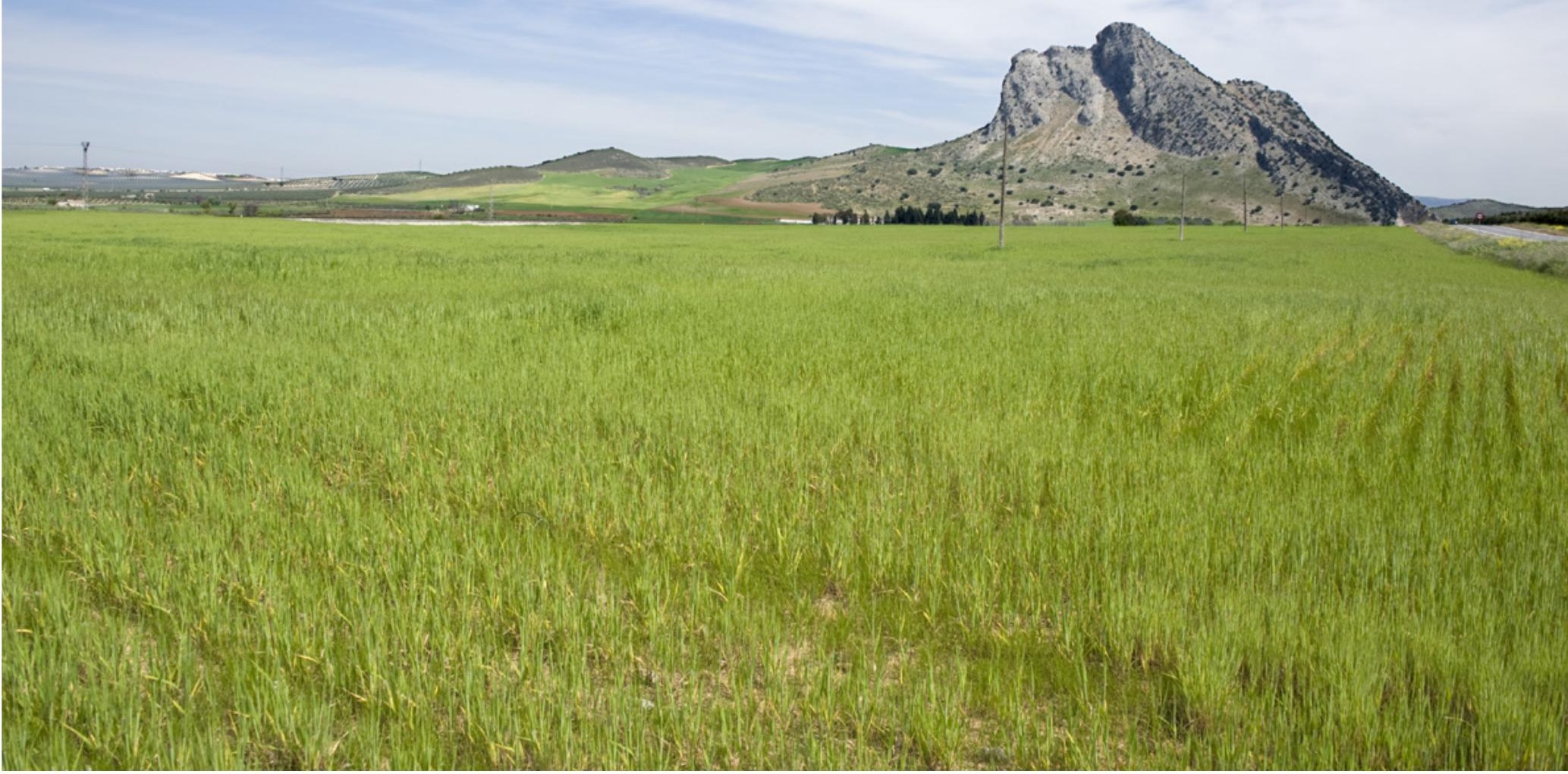

Paisaje recreado de la Peña de los Enamorados (Málaga) | foto Fondo Gráfico IAPH (Juan Carlos Cazalla) 


\section{ORIGEN, ALCANCE Y APORTACIONES DEL PROYECTO}

En 1992 la UNESCO incorporó la figura de "paisaje cultural" en sus directrices operativas para la aplicación de la Convención del Patrimonio Mundial Cultural y Natural. Los paisajes culturales son reconocidos desde entonces como bienes culturales que "ilustran la evolución de la sociedad humana a lo largo del tiempo, bajo la influencia de restricciones físicas y/o de las posibilidades de su entorno natural y de las fuerzas sociales, económicas y culturales sucesivas, tanto externas como internas" (DIRECTRICES, 2008).

En España diversas comunidades autónomas han integrado la figura de paisaje cultural en su legislación sectorial como Navarra, Murcia o La Rioja, mientras que en otros casos se han desarrollado figuras cercanas, aunque no coincidentes, con la de paisaje cultural como es el caso de Andalucía y las zonas patrimoniales definidas en su Ley 14/2007, de 26 de noviembre, de patrimonio histórico. No obstante, el reconocimiento expreso de los paisajes culturales como bienes culturales por parte de la UNESCO y la ratificación del Convenio Europeo del Paisaje por parte del Estado Español en 2008 conducen hacia un escenario de mayor presencia de esta nueva realidad en la gestión del patrimonio cultural.

En este contexto se enmarca el proyecto Registro de Paisajes de Interés Cultural de Andalucía (R-PICA). El atributo "de interés cultural" lo hace más cercano a otros bienes gestionados por las administraciones de cultura y evita el tradicional debate en relación con la existencia de componentes culturales en todos los paisajes. Es decir, se comparte la afirmación de que todos los paisajes, en mayor o menor medida, son culturales desde el momento en que es imprescindible la percepción humana para su propia existencia, pero no todos son "de interés" por los valores de su patrimonio cultural, sea este material o inmaterial.

Con el R-PICA se han cubierto los siguientes objetivos principales:

1. Construir una base conceptual, metodológica y operativa sobre la que basar la identificación y caracterización de paisajes significativos por sus valores culturales desde una aproximación interdisciplinar. Este objetivo ha permitido profundizar en el concepto de "paisaje cultural" así como en las diferentes aproximaciones a su análisis en función de la escala territorial y de la propia naturaleza de un registro próximo a un inventario exploratorio. Ello ha marcado, como se verá a lo largo de este artículo, el nivel de detalle en el análisis y en las recomendaciones planteadas, producto de la integración de visiones disciplinares complementarias. profesionales de la arqueología, geografía arquitectura, antropología, historia del arte y biología vinculados al IAPH y a las universidades de Sevilla y Pablo de Olavide.

Muy enriquecedoras también han sido las discusiones que se han producido en el seno del equipo de profesionales que ha trabajado en este proyecto ${ }^{1}$ 


\begin{tabular}{|c|c|c|}
\hline CATEGORIAS & TIPOS & SUBTIPOS \\
\hline \multirow{9}{*}{$\begin{array}{l}\text { A. Sistemas de } \\
\text { asentamiento }\end{array}$} & \multirow{6}{*}{ A.1 De dominante rural } & A.1.1 De poblados prehistóricos \\
\hline & & A.1.2 De poblados protohistóricos y romanos \\
\hline & & A.1.3 De pueblos de tradición medieval \\
\hline & & A.1.4 De nuevas poblaciones modernas \\
\hline & & A.1.5 De poblados de la industrialización \\
\hline & & A.1.6 De poblados de colonización agraria del siglo XX \\
\hline & \multirow{3}{*}{ A.2 De dominante urbana } & A.2.1 De ciudades romanas \\
\hline & & A.2.2 De ciudades de tradición medieval y moderna \\
\hline & & A.2.3 De las aglomeraciones urbanas históricas \\
\hline \multirow{7}{*}{$\begin{array}{l}\text { B. Sistemas de } \\
\text { comunicaciones y } \\
\text { transportes }\end{array}$} & \multirow{3}{*}{ B.1 De las infraestructuras del transporte } & B.1.1 Viarias \\
\hline & & B.1.2 Portuarias \\
\hline & & B.1.3 Ferroviarias \\
\hline & \multirow{4}{*}{ B.2 De pasos y vías naturales } & B.2.1 De pasos de montaña \\
\hline & & B.2.2 De estrechos marítimos \\
\hline & & B.2.3 De vías pecuarias \\
\hline & & B.2.4 De vías fluviales \\
\hline \multirow{4}{*}{$\begin{array}{l}\text { C. Sistemas de } \\
\text { seguridad y } \\
\text { defensa }\end{array}$} & \multirow[b]{2}{*}{ C.1 De posición } & C.1.1 Torres vigía \\
\hline & & C.1.2 Fortificaciones \\
\hline & \multirow{2}{*}{ C.2 De apoyo } & C. 2.1 Cuarteles \\
\hline & & C. 2.2 Bases militares \\
\hline \multirow{16}{*}{$\begin{array}{l}\text { D. Sistemas de } \\
\text { obtención y } \\
\text { transformación } \\
\text { de los recursos }\end{array}$} & \multirow{3}{*}{ D.1 De la caza, pesca y recolección } & D.1.1 Cinegético \\
\hline & & D.1.2 Pesquero \\
\hline & & D.1.3 Marisquero \\
\hline & \multirow{6}{*}{ D.2 Agrarios } & D.2.1 Agrosilvopastoril \\
\hline & & D.2.2 Vitivinícola \\
\hline & & D.2.3 Oleícola \\
\hline & & D.2.4 Del cereal \\
\hline & & D.2.5 De frutas $y$ hortalizas \\
\hline & & D.2.6 De policultivo \\
\hline & \multirow{5}{*}{ D.3 Mineros } & D.3.1 Calero \\
\hline & & D.3.2 Salinero \\
\hline & & D.3.3 Del mármol \\
\hline & & D.3.4 Del carbón \\
\hline & & D.3.5 De los metales \\
\hline & & D.4.1 De infraestructuras hidráulicas \\
\hline & D.4 Del agua y del viento & D.4.2 De molinos \\
\hline \multirow{5}{*}{$\begin{array}{l}\text { E. Sistemas } \\
\text { ideológicos y } \\
\text { asociativos }\end{array}$} & \multirow{3}{*}{ E.1 De las creencias, ritos y tradiciones } & E.1.1 Festivo - ceremonial \\
\hline & & E.1.2 Mágico-religioso \\
\hline & & E.1.3 Funerario \\
\hline & \multirow{2}{*}{ E.2 Del arte y la comunicación } & E.2.1 Creado \\
\hline & & E.2.2 Recreado \\
\hline
\end{tabular}

sobre la clasificación de los paisajes seleccionados, que han permitido diseTabla 1. Clasificación tipológica de los paisajes de interés cultural | tabla elaboración propia. Todas las tablas, mapas y gráficos son de los autores, si no se ñar un armazón en torno a 5 categorías, 12 tipos y 40 subtipos.

Con esta clasificación, de la que se publicó una primera versión con anterioridad (RODRIGO CÁMARA; DÍAZ IGLESIAS; FERNÁNDEZ CACHO et ál., 2012: 70), se ha pretendido ofrecer un marco global que pueda destacar los valores culturales que dan carácter a cada paisaje identificado. Las categorías y tipos pueden ser extrapolables a otros territorios fuera de Andalucía pero los subtipos podrían adaptarse a cada contexto geográfico, sobre todo los relacionados con la obtención y transformación de los recursos agrarios y mineros. También se ha realizado una clasificación por criterios espaciales que distribuye los paisajes en cuatro categorías: a) puntuales por emplazamiento (miradores) o referentes visuales (hitos); b) lineales por continuidad 
o interrelación; c) redes de malla continua o discontinua; y d) áreas delimitadas o difusas (RODRIGO CÁMARA; DÍAZ IGLESIAS; FERNÁNDEZ CACHO et ál., 2012: 71).

2. Elaborar un registro que incluye una selección de paisajes de interés cultural representativos del territorio andaluz. Se han identificado y caracterizado un total de 118 paisajes de interés cultural, a partir del diseño de una ficha de registro que incluye información identificativa básica y de localización, descripción e interpretación (clasificación y claves interpretativas), procesos históricos y actividades antrópicas más significativos para su conformación actual, imagen proyectada, protección natural y cultural y valoración, diagnóstico y recomendaciones. No obstante, este registro no está cerrado y se ha planteado la posibilidad de que se vayan incorporando otros paisajes a propuesta, también, de los agentes que los habitan, usan o administran.

3. Favorecer el conocimiento de los paisajes de interés cultural andaluces mediante la divulgación y la transferencia de resultados de la investigación. En este aspecto, son varias las iniciativas del IAPH para fomentar la divulgación en materia de paisaje. Mensualmente se incorpora información general sobre cada uno de los paisajes de interés cultural del registro en un canal web temático, y se difunde además a través de las redes sociales

Actualmente se trabaja también en la publicación de un producto multimedia que contenga toda la información del registro y que sea fácilmente accesible a través de la página web del IAPH, a la vez que se participa en actividades divulgativas como las Jornadas Europeas de Patrimonio, los Café con Ciencia o la Noche de los Investigadores, entre otras.

Para la transferencia de conocimiento se han realizado publicaciones y se ha participado en congresos y seminarios especializados, destacándose la labor docente desarrollada en cursos o a través de la atención a personas en régimen de estancia de formación o investigación que cualifican sus conocimientos y habilidades en esta materia. Se trata así de difundir entre la comunidad científica y profesional tanto el valor cultural de los paisajes identificados como la metodología de trabajo desarrollada en el IAPH para su conocimiento y registro. Esta metodología ya ha percolado en el Plan Nacional de Paisaje Cultural del Ministerio de Educación, Cultura y Deporte del Gobierno de España (IPCE, 2012), que también ha colaborado en la ejecución del R-PICA, o en la creación de otros registros similares al andaluz como el desarrollado en Asturias (FERNÁNDEZ SALINAS, 2013).

El siguiente desafío será implicar a la población local en la salvaguarda de estos paisajes haciéndoles partícipes del diseño de fórmulas innovadoras para su mejor protección, gestión y ordenación. 


\begin{tabular}{|c|c|}
\hline \multicolumn{2}{|c|}{118 PAISAJES DE INTERES CULTURAL DE ANDALUCIA } \\
\hline ALMERIA & CÁDIZ \\
\hline Paisaje agrario de Ohanes & Paisaje de Arcos de la Frontera \\
\hline Paisaje recreado del Desierto de Tabernas & Paisaje de Medina Sidonia \\
\hline Paisaje de los pueblos del Sur de los Filabres & Paisaje vitivinicola de Jerez de la Frontera \\
\hline Paisaje de Los Millares & Paisaje del Estrecho de Gibraltar \\
\hline Paisaje agrario de Bentarique & Paisaje de Castellar \\
\hline Paisaje minero de Rodalquilar & Paisaje recreado de la desembocadura del Guadalquivir \\
\hline Paisaje molinero del Barranco de Huebro & Paisaje de la Ensenada de Bolonia \\
\hline Paisaje salinero de Cabo de Gata & Paisaje de Vejer de la Frontera \\
\hline Paisaje minero de Gádor & Paisaje de Zahara de la Sierra \\
\hline Paisaje de Vélez-Blanco & Paisaje de Setenil de las Bodegas \\
\hline Paisaje de Tahal, Alcudia y Chercos & Paisaje del agua de la Manga de Villaluenga \\
\hline \multirow[t]{2}{*}{ Paisaje minero de Sierra Almagrera } & Paisaje de Grazalema \\
\hline & Paisaje molinero de Patrite \\
\hline CÓRDOBA & GRANADA \\
\hline Paisaje vitivinicola de Montilla & Paisaje agrario del Barranco del Poqueira y la Tahá \\
\hline Paisaje de Ategua y Torreparedones & Paisaje agrario del Valle de Lecrin \\
\hline Paisaje de Zuheros & Paisaje minero de Busquistar \\
\hline Paisaje del agua de Iznájar & Paisaje minero de la Sierra de Lújar \\
\hline Paisaje de Belalcázar & Paisaje agrario del Alto Rio Verde \\
\hline Paisaje de Dos Torres & Paisaje de Guadix y Purullena \\
\hline Paisaje de la Dehesa de la Jara & Paisaje recreado del Cerro de Jabalcón \\
\hline Paisaje recreado de la Sierra de Santa Eufemia & Paisaje de Castellón Alto \\
\hline Paisaje olvarero de Los Pedroches & Paisaje megalitico del Valle del Rio Gor \\
\hline Paisaje minero del Alto Guadiato & Paisaje recreado de La Sagra \\
\hline Paisaje de San Calixto & Paisaje de Castril \\
\hline Paisaje de la romeria de Obejo & Paisaje de Montefrio \\
\hline Paisaje minero de Cerro Muriano & Paisaje de Zagra \\
\hline Paisaje de Montoro & Paisaje del Paso de Zafarraya \\
\hline Paisaje de Almodóvar del Rio & Paisaje molinero de los Tajos de Alhama \\
\hline HUELVA & MÁLAGA \\
\hline Paisaje minero de Riotinto & Paisaje de los pueblos de la Axarquia Occidental \\
\hline Paisaje de Sanlúcar de Guadiana & Paisaje de Casares \\
\hline Paisaje de la Puebla de Guzmán & Paisaje de Ronda \\
\hline Paisaje de Paymogo & Paisaje agrario del Alto Genal \\
\hline Paisaje minero de Tharsis & Paisaje de Acinipo \\
\hline Paisaje de la romeria de Sotiel & Paisaje del agua de la Cueva del Gato \\
\hline Paisaje de la romeria de El Rocio & Paisaje del agua del El Chorro \\
\hline Paisaje de la defensa litoral de Doñana & Paisaje de Gaucin \\
\hline Paisaje molinero del rio Tinto & Paisaje de Teba \\
\hline Paisaje de Tejada la Vieja & Paisaje de Bobastro \\
\hline Paisaje pesquero de Isla Cristina & Paisaje de El Burgo \\
\hline Paisaje de la romeria de Alájar & Paisaje recreado de la Peña de los Enamorados \\
\hline Paisaje de la Dehesa del Chanza & Paisaje de la defensa litoral de Maro a Cerro Gordo \\
\hline \multicolumn{2}{|l|}{ Paisaje de Cumbres Mayores } \\
\hline \multicolumn{2}{|l|}{ Paisaje del agua de Cañaveral de León } \\
\hline JAÉN & SEVILLA \\
\hline Paisaje de Úbeda y Baeza & Paisaje agrario de Los Alcores y la Vega del Corbones \\
\hline Paisaje minero de Cástulo-Linares & Paisaje de Cote \\
\hline Paisaje de Alcalá la Real & Paisaje de Osuna \\
\hline Paisaje agrario de Pegalajar & Paisaje calero de Morón \\
\hline Paisaje de Otiñar & Paisaje de Estepa \\
\hline Paisaje olvarero de Sierra Mágina & Paisaje agrario de Carmona \\
\hline Paisaje del Paso de Despeñaperros & Paisaje agrario de isla Mayor \\
\hline Paisaje de Aldeaquemada & Paisaje molinero del rio Guadaira \\
\hline Paisaje de la romeria de Andújar & Paisaje agrario de Gerena \\
\hline Paisaje de Baños de la Encina & Paisaje minero del Cerro del Hierro \\
\hline Paisaje de Chiclana de Segura & Paisaje molinero del rio Huéznar \\
\hline Paisaje de Cazorla-La Iruela & Paisaje de Constantina \\
\hline Paisaje de Hornos & Paisaje de la romeria de Setefilla \\
\hline Paisaje recreado de El Yelmo & Paisaje de Mulva \\
\hline Paisaje recreado del nacimiento del Guadalquivir & Paisaje minero de Villanueva del Rio y Minas \\
\hline Paisaje del arte rupestre del Valle del Engarbo & Paisaje de Cazalla de la Sierra \\
\hline Paisaje del Paso de Quesada a Tiscar & Paisaje de Esquivel \\
\hline
\end{tabular}

Tabla 2. Paisajes de Interés Cultural de Andalucía 


\section{ENTRE CULTURA Y NATURALEZA}

Con carácter general, los componentes culturales de los paisajes se relacionan con las necesidades humanas de asentamiento, seguridad, comunicación, abastecimiento, producción o con su connotación ideológica. La adaptación al medio del ser humano ha variado a lo largo del tiempo igual que las características de las citadas necesidades y la capacidad técnica de influir en el medio físico en cada periodo histórico para satisfacerlas.

Los paisajes asociados a sistemas de seguridad y defensa suelen presentar fuertes discontinuidades formales, ya sea en los colores y formas, o en las texturas que los tapizan, fruto normalmente del encuentro de dos sistemas diferentes (plano de falla y borde litoral), o de procesos orogénicos y/o erosivos intensos, que ofrecen como resultado cumbres dominantes, planos verticales, acantilados y mesas elevadas respecto a un amplio entorno deprimido. La litología, pendientes y clima del entorno determinan generalmente el tipo de cobertura vegetal que acompaña estos paisajes, ya sea vegetación psammófila, olivares, pasto, matorral ralo, bosques de coníferas, de frondosas, o simplemente roca desnuda. Son, entre otros, los paisajes de Estepa y Cote, los cuales reflejan cómo el orden alomado de la campiña, margosa, sedimentaria, blanda, blanquecina y tostada, forrada de un bosque geométrico de olivos y un tapiz herbáceo de cereales y oleaginosas, verdes sobre claros, es capaz de trepar hasta asediar con sus olivos las rocas aflorantes de las principales cimas de las estribaciones subbéticas.

La base natural de los paisajes configurados por los sistemas de asentamiento es tremendamente variada. Los poblados prehistóricos aprovechan cualquier resalte topográfico en las zonas favorables. Éste es el caso de los paisajes de Los Millares o Castellón Alto, en los que se aprovechan de forma segura los recursos minerales y tróficos de sus respectivos entornos, a salvo de inundaciones, enemigos y predadores. Los poblados protohistóricos y romanos se ubican en zonas más abiertas y expuestas, próximas a los grandes ejes de comunicación natural (valles, campiñas y ríos), que sirven de transición entre los lugares de producción y comercialización o consumo. Así, los lugares prominentes de algunas campiñas son emplazamientos favorables para estos asentamientos, como en los casos de AteguaTorreparedones y Tejada la Vieja.

Los pueblos de tradición medieval expanden el poblamiento por todo el territorio, muy ligado al tipo de paisaje agrario, debido a que los trazados se insertan en la trama territorial de forma continua, con transiciones armónicas a través de sus ruedos. El paisaje tipo de las ciudades de tradición medieval y moderna repite este mismo patrón, solo que matizado por unas formas del territorio generalmente más suaves, aunque siempre emplazadas en balco- 
nes, cornisas o promontorios que permiten posiciones dominantes respecto a sus entornos (Ronda, úbeda, Baeza, Guadix).

Los paisajes de los sistemas de infraestructuras territoriales encuentran un vínculo especial con el manejo del agua. Los paisajes de la obra hidráulica abundan en entornos naturales, marcados por el desnivel, la interrupción, el salto o la abundancia hídrica, para evolucionar posteriormente hacia entornos ordenados, domesticados, fruto del uso de la infraestructura para el riego y el abastecimiento humano. Tonos azules, verdosos, con grano fino en las láminas de agua de los embalses, albercas y lagunas, tienen su réplica en el verdor geométrico del cultivo, cambiante en el año. La horizontalidad de los depósitos acuíferos se continúa con formas suaves en el caso de Sierra Morena (Cañaveral de León), más acusadas en el caso de las subbéticas cordobesas (Iznájar), y completamente verticales en los relieves kársticos de la serranías de Málaga (El Chorro), pasando de los tonos y texturas orgánicas a las minerales.

Protagonistas en extensión e intensidad son, por otra parte, los paisajes de la producción primaria. Son paisajes abiertos, llanos u ondulados, repletos de rayas, puntos y estructuras repetitivas que se extienden como un manto continuo a lo largo y ancho de la capa sedimentaria del valle del Guadalquivir, su vega y su campiña, dadas las condiciones edáficas de profundidad, nutrientes y humedad que proporcionan su estable y deprimida posición topográfica. Un paisaje de horizontes abiertos (Gerena y Carmona) hasta su confluencia con el piedemonte de las elevaciones hercínicas y béticas, donde las cuencas visuales se independizan en pequeños valles tachonados por más olivos, cereales y oleaginosas (Los Pedroches y Setenil de las Bodegas), pasando entonces a dominar en una parte del año las texturas granulosas de tipo medio y fino, frente a las texturas lisas y monocromáticas que predominan en los cereales de la llanura sedimentaria.

En las campiñas altas el aspecto es muy variable, alomado (Molinos en Alhama) o inclinados en cerros empinados, como en la subbética cordobesa (Zuheros). Los bordes de la cubeta sedimentaria del Guadalquivir, de verdes oscuros y tonos pardos, se dibujan suavemente al norte (Gerena), en las onduladas elevaciones desgastadas de Sierra Morena, que soportan otro gran paisaje productivo andaluz, la dehesa (Llanos del Chanza). Dehesa también al sur de la cubeta, pero ya sobre laderas más inclinadas y cerros prominentes, los del bético (Alto Genal) y el flysh (Estrecho de Gibraltar, Vejer de la Frontera), de grano más abierto aún por la mayor laxitud de su arboleda y la menor proporción de matorral.

Los paisajes agrarios se extienden más allá de la vertical practicable, o de la precipitación indispensable, donde el agua de deshielo, o las reservas subterráneas nutren bancales, balates y terrazas, que introducen la horizontalidad 
en un entorno vertical dominado por la gravedad o la aridez, que transforman la uniformidad cromática y morfológica de pendientes y llanos arrasados por la deforestación, a través del desarrollo y fructificación de múltiples cultivos. El mundo bético las conoce muy bien, especialmente las sierras de Gádor (Ohanes), la sierra de los Filabres (sur de los Filabres, Tahal, Alcudia de Monteagud y Chercos), María (Vélez-Blanco) y Nevada (Poqueira y La Tahá, valle de Lecrín), así como cauces como el río Andarax (Bentarique) o arroyos como la ribera de los Molinos (barranco del Huebro, en Níjar).

Los paisajes vinculados a sistemas ideológicos y asociativos están generalmente muy ligados a determinados hitos territoriales, por lo que suelen resultar bastante heterogéneos en función de donde se hallen. En cualquier caso, podría decirse que este tipo de paisajes tienen en común una belleza solitaria y definida por rasgos profundamente naturales. Es por ello que variables necesarias en estos paisajes como el misterio, la fábula y la leyenda, tienen terreno abonado en lugares en los que la fuerza de la naturaleza manifestada a través de la rotundidad de la piedra, la inmensidad del cielo, el abismo de la altura. Paisajes como Tíscar, de ingentes moles pétreas, El Rocío, última mota de tierra practicable en los confines de la pluvisilva atlántica y los bosques lianoides, o Andújar, sumergida en el bosque mediterráneo más montaraz e intrincado de toda Sierra Morena, son buenos ejemplos de todo ello.

\section{CARACTERÍSTICAS DE LA DOCUMENTACIÓN GRÁFICA}

Para la realización del R-PICA se ha realizado una intensa recopilación de imágenes, imprescindibles para su documentación y transmisión al conjunto de la sociedad entre las que se incluyen imágenes multirresolución, de $360^{\circ}$ y, sobre todo, panorámicas. Son, sin embargo, los videos inmersivos los que permiten un mayor acercamiento a la percepción que tendría cualquier persona que los visite (Setenil de las Bodegas, Ensenada de Bolonia, Sanlúcar de Guadiana, Riotinto, Carmona y Cerro del Hierro) permitiendo el desplazamiento por la propia imagen en movimiento, ver y oír (http://www.iaph.es/ imagenes-patrimonio-cultural-andalucia/imagenes360.php).

En cuanto a la información espacial, los paisajes del R-PICA no han sido por ahora objeto de una delimitación precisa, restringiéndose esta labor a la definición de su marco general de localización, con una superficie variable entre los 30 y $80 \mathrm{~km}^{2}$ en la mayoría de ellos pero llegando en algunos casos a los $170 \mathrm{~km}^{2}$.

La ficha individual de cada paisaje del registro se acompaña de una documentación cartográfica compuesta por tres salidas gráficas normalizadas: dos mapas básicos de contextualización (regional y supramunicipal) y un tercero que se corresponde con el marco de localización de cada paisaje a escala local (mapa 1). 


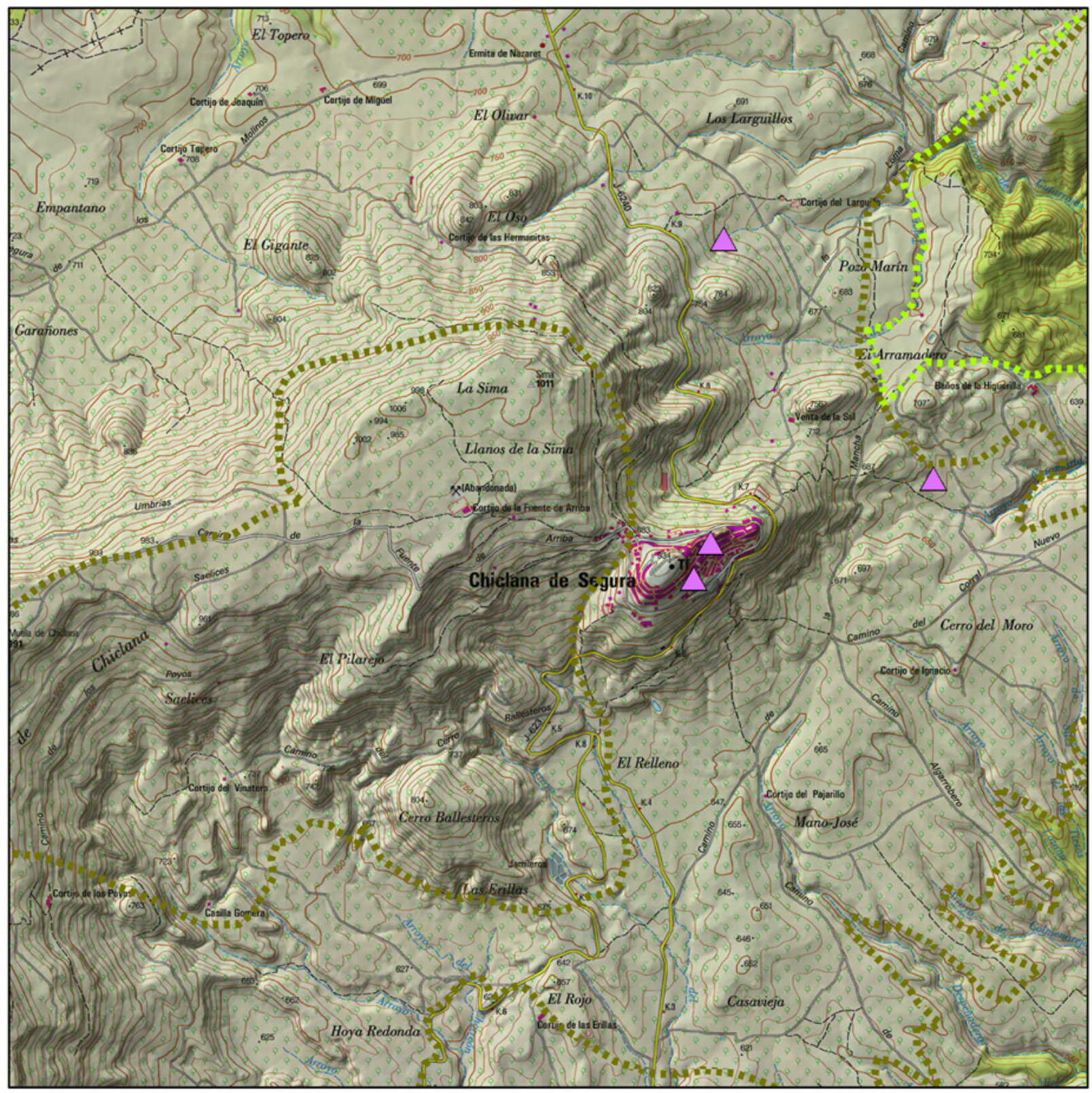

\begin{tabular}{|c||c||c|c|}
\hline \multicolumn{1}{|c||}{ Sistema del Patrimonio Territorial } & \multicolumn{1}{c|}{ Cartografia base } \\
\hline \multicolumn{2}{|c|}{ PATRIMONIO CULTURAL } \\
Demarcaciones de Paisaje Cultural
\end{tabular}

Mapa 1. Ejemplo de mapa del Sistema de Patrimonio Territorial del Paisaje de pueblos de tradición medieval en Chiclana de Segura (Jaén) 
La finalidad de este último es representar y transmitir de forma sintética los elementos más relevantes de cada paisaje, junto a los principales recursos del sistema de patrimonio territorial. Para ello se han establecido tres formatos básicos de salida que permiten la representación de casi todos los paisajes de interés cultural en un rango de escala entre 1:20.000 y 1:40.000, con excepciones puntuales para la representación de algunos de ellos a una escala menor. Los datos espaciales utilizados para esta salida cartográfica son:

a) Como cartografía base, el mapa topográfico nacional 1:25.000 proporcionado por el Centro Nacional de Información Geográfica. Se trata de un producto que aúna información compilada sobre la representación del relieve con sombreado, hidrografía, usos del suelo (vegetación y cultivos), infraestructuras, núcleos de población, así como un interesante acervo toponímico.

b) Como cartografía temática, se ha empleado una selección de información espacial del Sistema del Patrimonio Territorial de Andalucía elaborados por la Consejería de Cultura, UNESCO y la Red de Información Ambiental de Andalucía.

Mapa 2. Análisis de visibilidad en el Paisaje de Cote

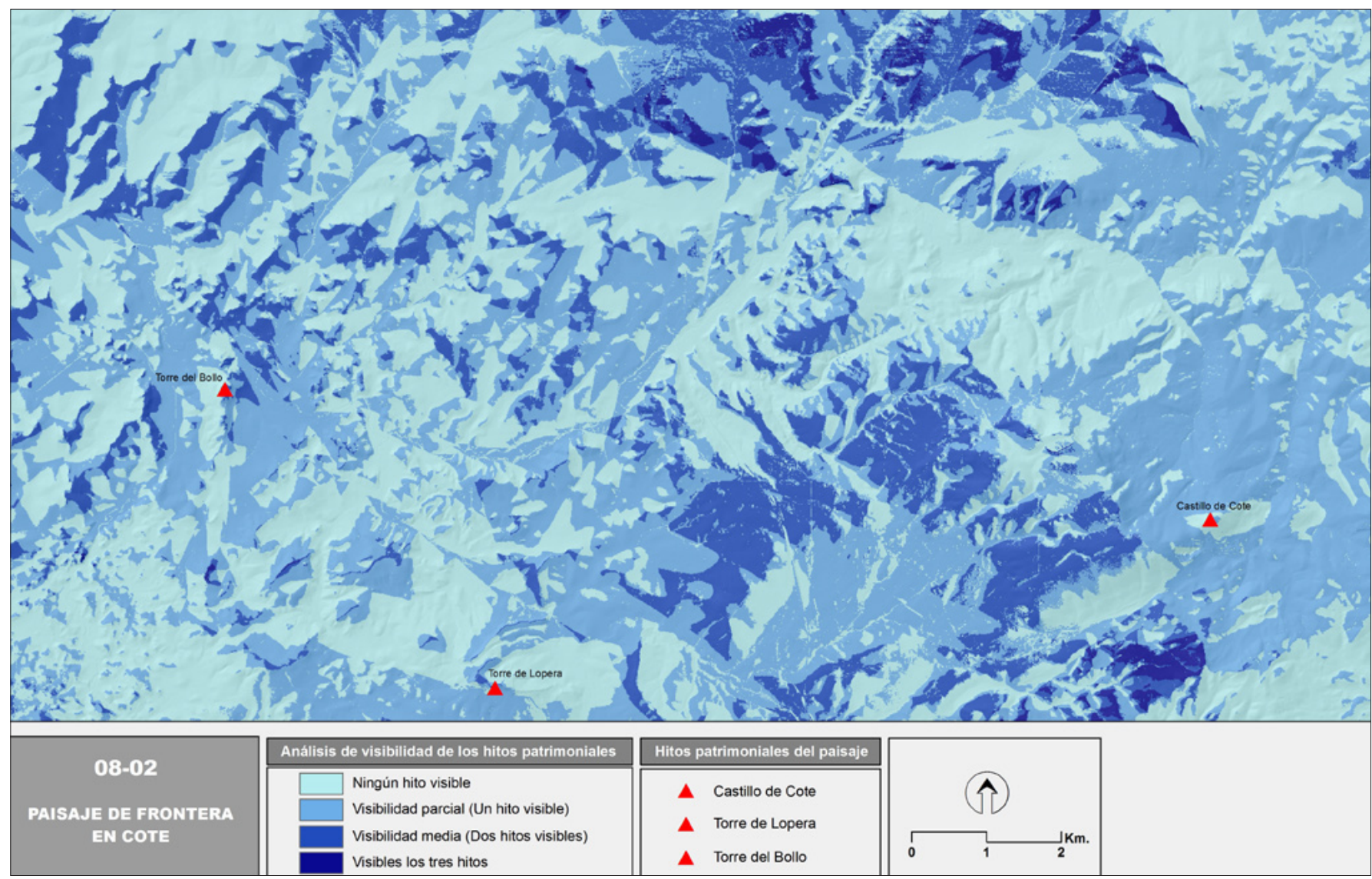


La documentación gráfica se completa con:

> Un análisis de visibilidad en aquellos paisajes cuya clasificación espacial haga referencia a su carácter de referente visual del territorio o de mirador (mapa 2). Estos análisis ayudan a delimitar las áreas más sensibles para el mantenimiento de los valores paisajísticos asociados al patrimonio cultural en estos lugares.

$>$ Un esquema coremático para sintetizar la estructura de asentamientos actual y el esquema de la clasificación espacial de cada paisaje (RODRIGO CÁMARA; DÍAZ IGLESIAS; FERNÁNDEZ CACHO et ál., 2012: 71-72).

$>$ Un corte-diagrama realizado sobre aquel ámbito que expresa mejor el carácter del paisaje, en el que quedan identificados los elementos principales que pueden ser tanto bióticos como abióticos (RODRIGO CÁMARA; DÍAZ IGLESIAS; FERNÁNDEZ CACHO et ál., 2012: 72-73).

\section{DISTRIBUCIÓN TERRITORIAL Y TIPOLÓGICA DE LOS PAISAJES DE INTERÉS CULTURAL DE ANDALUCÍA}

Tomando como punto de partida la distribución regional del R-PICA (mapa 3), es posible abordar diversos análisis para contextualizar esta información con los resultados de otras iniciativas que se han realizado sobre el paisaje andaluz. El Mapa de Paisajes de Andalucía presenta un sistema de clasificación jerarquizada en categorías, áreas, ámbitos y unidades de paisajes. De entre ellas, las categorías paisajísticas establecen una primera clasificación sintética que sirve de referencia para la agrupación de los paisajes andaluces en seis grandes grupos en función de criterios morfológicos y de usos del suelo (ATLAS, 2005).

Un análisis conjunto permite avanzar una valoración general de la fisonomía del medio en el que se insertan los paisajes de interés cultural registrados y que muestra una correlación bastante alta entre la superficie de cada categoría paisajística y el número de paisajes localizados en cada una de ellas (tabla 3).

Analizando la distribución tipológica de los paisajes de interés cultural documentados en cada una de las cinco grandes categorías del Mapa de Paisajes de Andalucía se observan las siguientes tendencias:

a) Paisajes serranos. Se contabilizan algo más de la mitad de los paisajes registrados: 37 en las áreas de media montaña y 24 en los de baja montaña. Los más representativos son los relacionados con la obtención y transformación de los recursos agrarios silvopastoriles -ganadería, bosques, dehesas, actividades tradicionales del ámbito serrano. Le siguen los paisajes de la seguridad y defensa posicional de fortalezas, vinculados a la protección de los territorios que marcaban principalmente las franjas defensivas históricas 


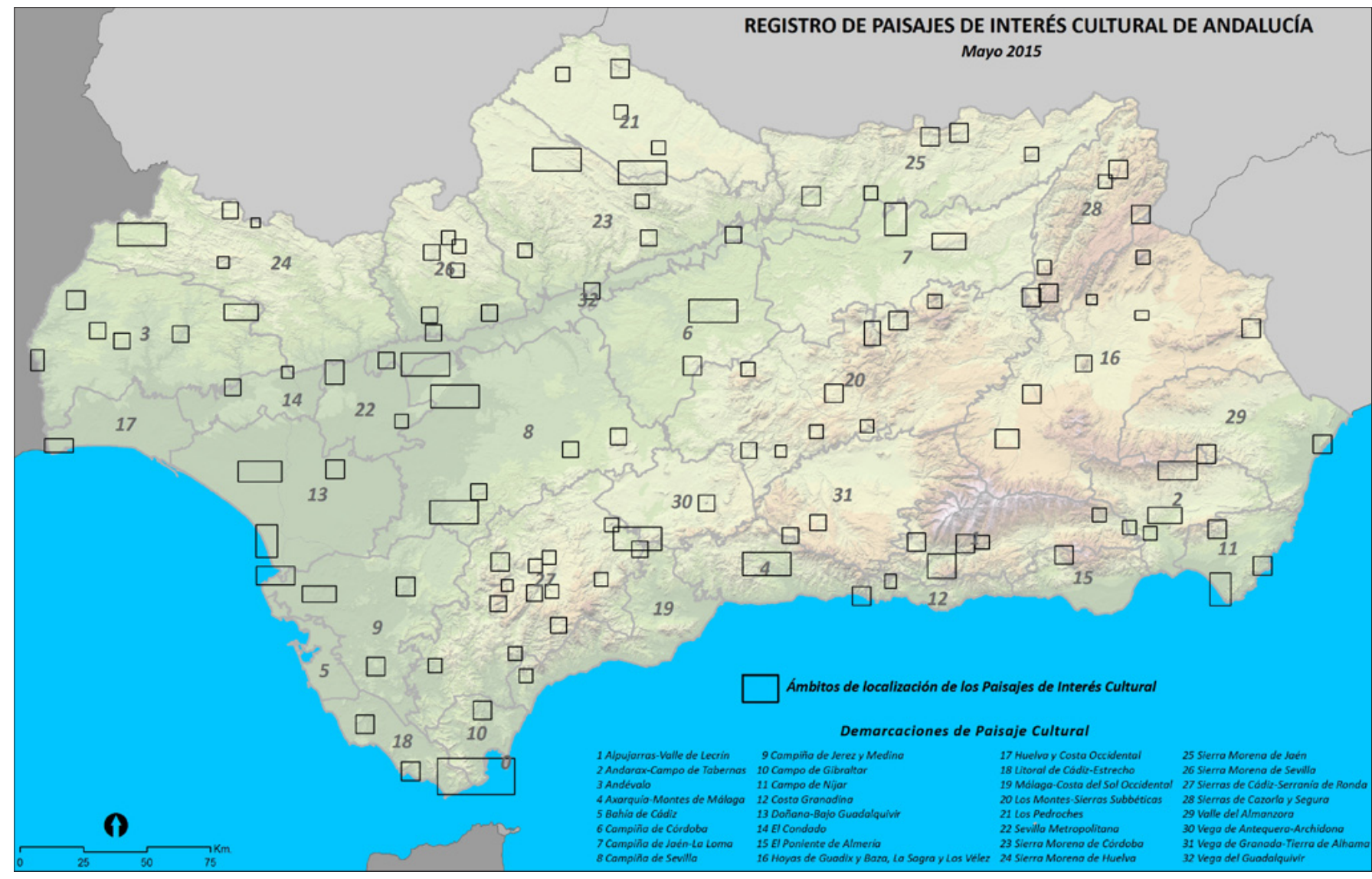

Mapa 3. Mapa de distribución regional de los Paisajes de Interés Cultural de Andalucía

Tabla 3. Categorías de paisajes andaluces y paisajes de interés cultural

\begin{tabular}{|l|r|r|r|c|}
\hline \multicolumn{1}{|c|}{ Categoría } & $\begin{array}{c}\text { Superficie } \\
\text { categoría (Has) }\end{array}$ & $\begin{array}{c}\text { \% Sup. } \\
\text { Categoria }\end{array}$ & N.0 PIC & $\begin{array}{c}\text { \% n. }{ }^{\circ} \text { PIC / Total } \\
\text { PIC (118) }\end{array}$ \\
\hline Paisajes Serranos & 3.879 .809 & 43,68 & 61 & 51,7 \\
\hline Paisajes de Campiña & 3.000 .000 & 31,09 & 29 & 24,57 \\
\hline Paisajes de Valles, Vegas y Marismas & 920.211 & 10,36 & 12 & 10,1 \\
\hline Paisajes de Altiplanos y Subdesiertos esteparios & 627.380 & 7,09 & 5 & 4,24 \\
\hline Paisajes Litorales & 500.000 & 5,82 & 11 & 9,32
\end{tabular}

medievales. Los asentamientos de dominante rural de pueblos de tradición medieval relacionados con la reconquista castellana representan la siguiente tipología, seguida de los paisajes de la obtención y transformación de los recursos metalíferos, explotados en determinadas etapas históricas en los territorios de Sierra Morena y el Sistema Penibético. El último subtipo incluye a los paisajes relacionados con actividades festivo-ceremoniales.

b) Paisajes de campiña. Con 29 paisajes registrados suponen casi un $25 \%$ del total. Esta categoría se extiende mayoritariamente a lo largo de la depresión del Guadalquivir. Según su clasificación destacan los asociados a pueblos de tradición medieval, a la seguridad y defensa posicional, obtención y 
transformación de los recursos agrarios (del cereal y oleícolas) y, por último, a los poblados protohistóricos y romanos.

c) Paisajes de valles, vegas y marismas. Con algo más del 10\% de los paisajes registrados, predominan los paisajes de la obtención y transformación de los recursos agrarios (fundamentalmente cereal, frutas y hortalizas y policultivo) del cereal, seguidos por los conformados por pueblos de tradición medieval y por los de la seguridad y defensa posicional.

d) Paisajes litorales. Los cinco subtipos predominantes son los de las torres vigías, en la costa onubense y malagueña, los recreados, los de la obtención y transformación de los recursos mineros (metales), principalmente en las sierras del litoral almeriense y, finalmente, de la obtención y transformación de los recursos pesqueros y salineros, en ambos casos actividades características del litoral.

e) Paisajes de altiplanos y subdesiertos esteparios. El bajo número de paisajes registrados (5) no permite extraer datos relevantes sobre la tipología predominante.

Por otra parte, a partir de la clasificación típológica (tabla 1) cada paisaje de interés cultural ha podido ser asignado a un único subtipo de paisaje que se ha denominado "principal" y, opcionalmente, a uno o varios subtipos que se han denominado "accesorios". Esta fórmula ha asegurado una completa caracterización de cada paisaje con sus matices de acuerdo al tratamiento holístico y transversal que supone esta lectura cultural. Un análisis exploratorio de dicha clasificación concluye que casi un 40\% del total de los paisajes registrados se asocian a sistemas de obtención y transformación de los recursos y cerca de un $25 \%$ a sistemas de asentamiento. Por debajo del 15\% se sitúan, por orden, los de los sistemas de seguridad y defensa, ideológicos y asociativos y, por último, los de los sistemas de comunicaciones y transportes (gráfico 1).

En la lectura por los 12 tipos casi el 30\% del peso recae en los paisajes de la obtención y transformación de los recursos agrarios, seguidos de los de asentamientos de dominante rural y de la seguridad y defensa posicional. Hay que destacar que muchos de los paisajes de los dos últimos tipos citados integran numerosos valores culturales vinculados con la explotación agraria del territorio inmediato, aportando una rica lectura cultural adicional a la que proporciona el subtipo principal (gráfico 2).

Por último, se analizan los 5 subtipos más representados (gráfico 3) que suponen más del $50 \%$ de registro. Ello aporta una visión de los paisajes andaluces como los de un territorio cultural y patrimonial de asentamientos rurales en un espacio muy significado por los elementos de la defensa como castillos y

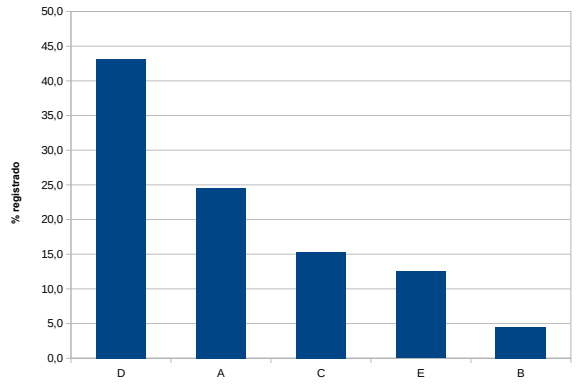

Gráfico 1. Distribución de paisajes de interés cultural por categorías

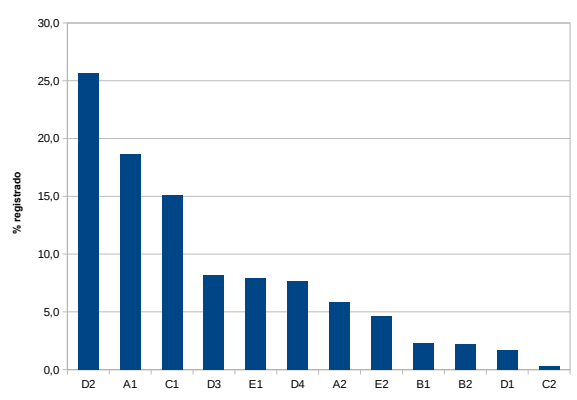

Gráfico 2. Distribución de paisajes de interés cultural por tipos

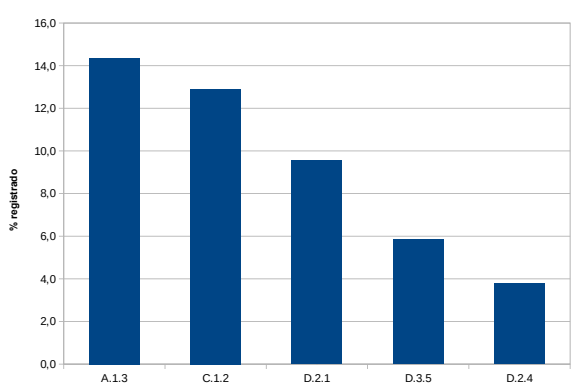

Gráfico 3. Distribución de paisajes de interés cultural por subtipos principales 
Mapa 4. Subtipo A.1.3. Distribución según su representación en las demarcaciones de paisaje cultural
Mapa 5. Subtipo C.1.2. Distribución según su representación en las demarcaciones de paisaje cultural

Mapa 6. Subtipo D.2.1. Distribución según su representación en las demarcaciones de paisaje cultural
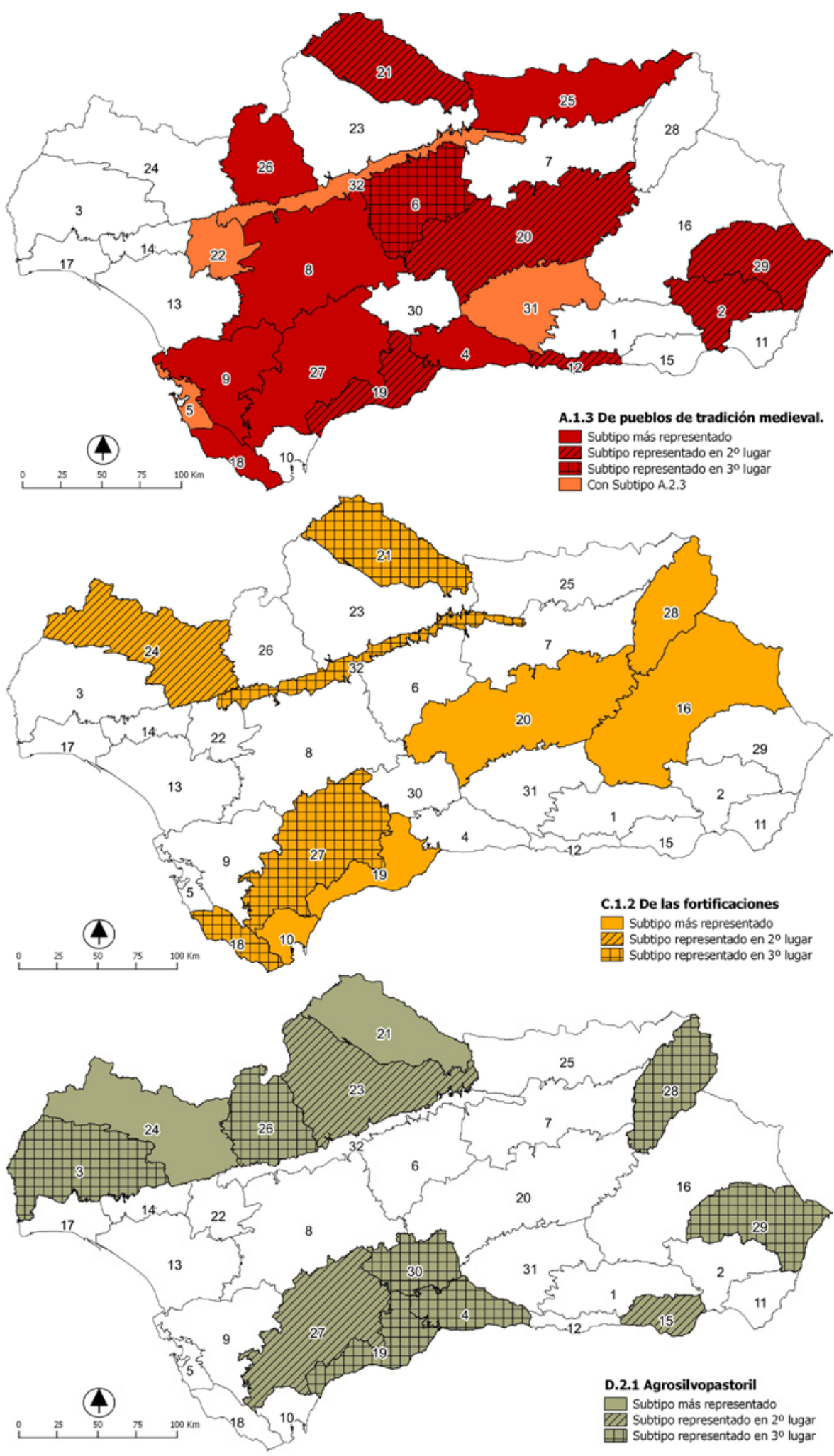
fortalezas, acompañados de unos paisajes de gran valor cultural vinculados con la explotación -obtención y transformación-agraria y minera.

Estos datos pueden expresarse de forma cartográfica, en el mismo orden, para los 3 subtipos principales.

1. El subtipo A.1.3 (de pueblos de tradición medieval) muestra una amplia representación (mapa 4). Las demarcaciones paisajísticas de la franja central de Andalucía (Sierra Morena de Sevilla -26-, Campiña de Sevilla -8-, Campiña de Jerez y Medina -9-, Litoral de Cádiz y Estrecho -18-, Sierras de Cádiz y Serranía de Ronda -27-) son las que muestran el mayor número de paisajes de este subtipo. Si se añaden los que pertenecen a los paisajes de las aglomeraciones históricas urbanas, se hace visible, a nivel general, una coherencia territorial del propio valle del Guadalquivir y las potentes áreas de campiña con el peso de los procesos históricos de urbanización en el medio rural. Estos procesos se estaban produciendo desde la época romana y aportan finalmente, en la época medieval y moderna, una de las configuraciones con mayor densidad de asentamientos de porte medio en la Península Ibérica.

2. El subtipo vinculado con la defensa territorial posicional de las fortificaciones ofrece una lectura muy clara de acuerdo con los procesos medievales de la frontera granadina en los casos de los montes y sierras Subbéticas (20), Sierras de Cazorla y Segura (28) y Hoyas de Guadix, Baza y Los Vélez (16), a las cuales habría que añadir la demarcación de las sierras de Cádiz y Serranía de Ronda (27) con este subtipo elegido como tercera opción (mapa 5).

3. En el subtipo asociado a los aprovechamientos silvopastoriles destacan los medios agroforestales de las dehesas andaluzas tan significativas en las áreas serranas del norte de Andalucía (mapa 6). Desde la frontera portuguesa, con las demarcaciones del Andévalo (3), y Sierra Morena de Huelva (24), hasta los Pedroches (21), interconectadas por la Sierra Morena de Sevilla (26) y de Córdoba (23).

En otros sectores regionales destacan las áreas de gestión forestal de las Sierras de Cazorla y Segura (28), o las de los paisajes adehesados de los Alcornocales, los castañares malagueños del Genal o los ámbitos más puramente forestales de Grazalema, todos en la demarcación 27, sierras de Cádiz y Serranía de Ronda.

\section{INSTRUMENTOS DE PROTECCIÓN, GESTIÓN Y ORDENACIÓN DE LOS PAISAJES DE INTERÉS CULTURAL}

Los paisajes de interés cultural deberían empezar a ser considerados como otro de los elementos que conforman el Sistema Regional de Protección del 
Territorio que define el Plan de Ordenación del Territorio de Andalucía (2007) $y$, en consecuencia, ser tomados en cuenta en los procesos de planificación territorial. La documentación de los paisajes de interés cultural incluye el análisis de las distintas figuras de ordenación, protección y gestión que recaen sobre los ámbitos seleccionados, que comprenden la ordenación territorial a escala subregional, el urbanismo y la protección natural y cultural. En el caso de los ámbitos subregionales, 14 de los 18 documentos aprobados albergan paisajes de interés cultural, en concreto 36 de los 118 que comprende el R-PICA.

La acción planificadora que establecen los planes subregionales se desarroIla con detalle en el planeamiento urbanístico municipal. A efectos de este proyecto se han tratado las circunstancias urbanísticas que se refieren a continuación:

1. Municipios en los que se localizan los paisajes de interés cultural. El $73 \%$ de los paisajes estudiados se localiza en un único municipio que asume íntegramente su gestión. Sin embargo los planes urbanísticos municipales se mueven en un arco cronológico de unos 30 años lo que, junto a las características de la población, su relevancia territorial, etc., propician un tratamiento muy diferente en cada ámbito aunque, en líneas generales, e independientemente del tipo y rango del documento vigente, la mayoría ha garantizado la protección del paisaje como en los casos de Zuheros, Manga de Villaluega, Gaucín o Belalcázar. En resumen puede afirmarse que el grado de conservación del paisaje no depende tanto del tipo de documento ni de su antigüedad sino de su calidad, hasta el punto de que algunas delimitaciones de suelo urbano del año 1978 los regulan con mejor diligencia que extensos articulados de algún Plan General de Ordenación Urbana reciente.

Los paisajes registrados que se ubican en dos o más municipios están sujetos a distintos planeamientos y gestiones urbanísticas, pudiendo verse afectados por normas y criterios muy diferentes como en el valle de Lecrín, Riotinto, la dehesa de la Jara o Cazorla-La Iruela. En otros casos, los distintos municipios pueden tener criterios patrimoniales análogos, pero no suficientes para garantizar su conservación como ocurre en el Alto Genal o el sur de los Filabres o, como en el caso del Barranco del Poqueira y la Tahá, desarrollar unas Normas Subsidiarias de Planeamiento para el conjunto de los tres municipios afectados: Capileira, Bubión y Pampaneira. En cualquiera de los casos citados el territorio podría ser ordenado mediante un Plan Especial de Paisaje, además de ser incluidos en los planes de ordenación del territorio de ámbito subregional, según se ha explicado más arriba.

2. Protecciones de carácter paisajístico en el planeamiento. El $97 \%$ de los paisajes documentados se encuentra al menos parcialmente protegido. En 
la mayoría de los casos sus suelos se clasifican como no urbanizables de especial protección bajo diferentes categorías: interés arqueológico, interés agrícola, interés ambiental, etc. La mayoría de estas protecciones provienen de instrumentos de rango supramunicipal, como los planes especiales de protección del medio físico, los planes de ordenación del territorio, otras normativas sectoriales, etc. En líneas generales, los paisajes que conforman el R-PICA gozan de protecciones ambientales, patrimoniales y territoriales.

3. Crecimientos urbanísticos planificados. La gran capacidad del agente urbanizador para transformar el territorio lo convierte en un elemento fundamental a considerar cuando se plantean acciones para la preservación del paisaje, por lo que la incidencia de los suelos urbanizables en el ámbito de los paisajes de interés cultural es un aspecto crucial del análisis territorial. En este sentido, el $11 \%$ de ellos presenta problemas de distinta índole respecto a los crecimientos urbanísticos planificados.

En Andalucía se dan múltiples y diversas situaciones en este sentido, encontrándose ciudades medias que han diseñado nuevos crecimientos sin alterar gravemente la implantación de la población como en el caso de Estepa, junto a otras zonas donde no se ha desarrollado el suelo previsto como en Villanueva del Río y Minas.

En algunos lugares se han previsto suelos urbanizables que no se han desarrollado plenamente $y$, a pesar de ello, se expande sin control la construcción en suelo no urbanizable como en Vejer de la Frontera y, en otros, se ha planificado suelo urbanizable con incidencia en paisajes de interés cultural como el agrario del Alto Río Verde en Granada. En conjunto se constata que el $11 \%$ de los paisajes de interés cultural registrado presenta problemas de distinta índole respecto a los crecimientos urbanísticos planificados.

4. Estudios específicos de paisaje. También se ha estudiado si el planeamiento urbanístico trata el paisaje como elemento a ordenar, gestionar y proteger, partiendo de que el concepto "paisaje" no tiene por qué explicitarse mediante este término ya que a veces se trata desde la visibilidad, otras desde sus aspectos ambientales o culturales, etc. En este sentido, se ha comprobado que el $76 \%$ de los planes estudia directamente esta cuestión como en los casos de Vélez-Blanco, Arcos de la Frontera, Obejo, Alcalá la Real, etc.

Toda la información analizada nos confirma que existe una importante relación entre el paisaje que percibimos y la planificación urbana y territorial que le afecta y que, muy frecuentemente, los desarrollos urbanos materializados y las protecciones asignadas explican gran parte de su permanencia hasta nuestros días. 


\section{LAS PERCEPCIONES Y LOS PAISAJES DE INTERÉS CULTURAL}

Las percepciones sociales han estado presentes desde el principio en el análisis de los paisajes del R-PICA. Forman parte del imaginario colectivo ya que se se trata de ideas sancionadas socialmente, que son compartidas por quienes integran un determinado contexto social, conformadas a partir de diferentes dimensiones sociales, políticas, religiosas, económicas, etc., y que se transforman a lo largo del tiempo en función de los cambios producidos en la esfera social, política, religiosa, económica, etc. Las percepciones sociales implican, por tanto, dinamismo, acción, posicionamiento y toma de decisiones sobre la realidad, ya que en función de cómo se perciba esta se generará un determinado pensamiento del que derivará una acción. De ahí el interés y la potencia explicativa de las percepciones a la hora de analizar el paisaje.

La aproximación realizada a las percepciones sociales en el R-PICA tiene como antecedente el proyecto que le precedió (FERNÁNDEZ CACHO; FERNÁNDEZ SALINAS; HERNÁNDEZ LEÓN et ál., 2010) a través del análisis de las imágenes proyectadas de los paisajes andaluces mediante su formalización en descripciones y citas relacionadas que se entendieron representativas del conjunto de 32 demarcaciones paisajísticas en las que se desagregó el territorio andaluz (QUINTERO MORÓN; HERNÁNDEZ LEÓN, 2012). En el caso de los paisajes de interés cultural, aunque la escala local de análisis de cada uno de ellos haría necesaria una mayor concreción en el análisis de las percepciones, el hecho de que se trate de nuevo de un proyecto de alcance regional ha hecho necesario recurrir de nuevo una aproximación a ellas a través de las imágenes proyectadas.

A través del análisis del marco temporal y el perfil de las fuentes de información utilizadas en la recopilación de imágenes proyectadas en los paisajes registrados se ha constatado su amplio marco cronológico y enorme diversidad.

Es en la antigüedad (época romana fundamentalmente) cuando se localizan los primeros productores de imágenes, vinculados a la historia y la geografía. No obstante, será a partir del siglo XI cuando la secuencia cronológica de las imágenes recopiladas tiene lugar de forma continuada y constante hasta la actualidad. Si en el siglo XI el protagonista es el romancero popular, el siglo XII incorpora la mirada geográfica y el XIII suma la historia y la versión de la historia que transmiten los documentos jurídico-administratativos (tratados, privilegios y repartimientos...). En el siglo XIV al protagonismo de los historiadores se les une el de los cronistas y a dichos perfiles se suman en el siglo XV poetas y geógrafos. El siglo XVI añade a escribanos, escritores, historiadores con visión geográfica, funcionarios y miembros de la nobleza y la aristocracia. En el siglo XVII destacan los testimonios de escritores, sacer- 
dotes, dramaturgos, cartógrafos y se incorpora la figura del viajero y la información que aportan los diccionarios geográfico-estadísticos y el catastro. El siglo XVIII destaca por dar voz a ingenieros y naturalistas, complementados en el siglo XIX por arqueólogos y botánicos. El siglo XX suma a fotógrafos, ecologistas, periodistas, pregoneros, antropólogos, espeleólogos y economistas, además de a poetas y novelistas que en este siglo adquieren relevancia en sus aportaciones. La irrupción del mundo digital a final del siglo también se refleja en la proyección que se realiza sobre los paisajes andaluces, aunque en este momento vinculada fundamentalmente a instituciones, destacando las guías turísticas digitales. El siglo XXI muestra el predominio de informantes que proyectan sus visiones sobre los paisajes a través del mundo digital y la redes sociales, mediante blogs, portales comerciales (básicamente turísticos e inmobiliarios) e institucionales.

Al poner el acento en las correlaciones existentes entre las imágenes proyectadas y los perfiles de los informantes se observa una serie de tendencias.

La descripción de hechos singulares, acontecimientos históricos y el origen de las denominaciones es objeto de cronistas e historiadores que intentan reflejar lo acontecido en torno a ellos con la mayor fidelidad. El cancionero popular también ha permitido conservar en el imaginario colectivo hechos asociados a enfrentamientos, recogiendo el cerco a ciudades o los lamentos por la pérdida de importantes plazas. Este es el caso del úbeda y Baeza cuyas imágenes proyectadas incluyen el primer romance fronterizo conocido.

En los poetas, dramaturgos, novelistas y escritores emergen los sentimientos asociados a los paisajes. En sus imágenes prima la conversión de los paisajes en el fondo de sus obras y en los argumentos de sus relatos y poesías, aunque también se ensalza la belleza de los elementos que los componen, mostrando a veces su sorpresa y la emoción que les embarga por las características de ciertos paisajes o escenas contempladas.

Los historiadores, geógrafos, economistas y especialistas en ciertas materias (arqueología, antropología, botánica, ingeniería, agronomía, espeleología) proyectan imágenes descriptivas más asépticas sobre la realidad que analizan, a menudo centrándose en la revisión de hechos o la enumeración de recursos y actividades.

Los viajeros tienen en común el interés por la descripción de los lugares por los que pasan o visitan bajo el formato de guías de viajes. Esto explica la presencia de juicios de valor sobre lo que contemplan, conocen o les cuentan y la construcción de una mirada que subraya o los aspectos positivos de los paisajes que son susceptibles de ser conocidos o aquellos más negativos 
Paisaje agrario de Ohanes (Almería) | foto Fondo Gráfico IAPH (José María Rodrigo)

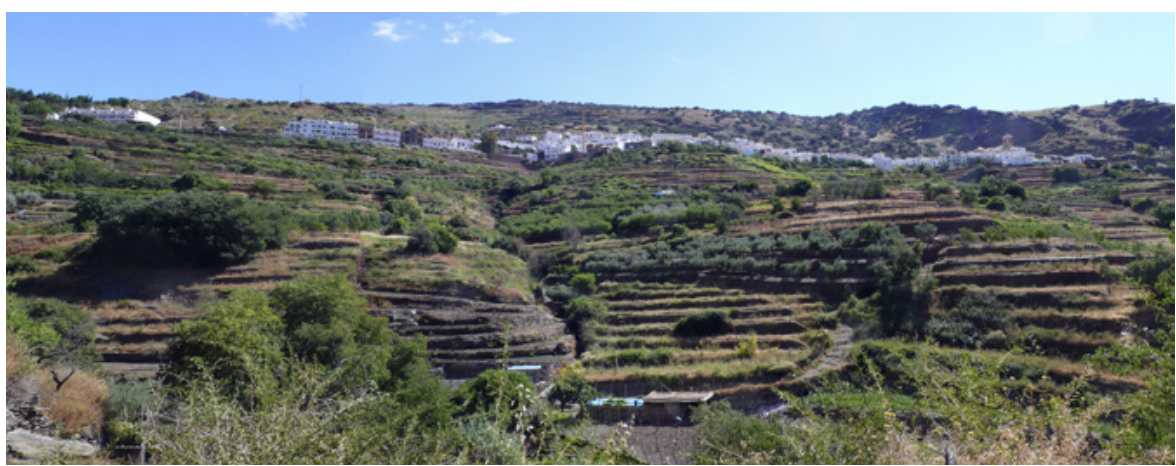

Paisaje minero del Cerro del Hierro (Sevilla) | foto Fondo Gráfico IAPH (Juan Carlos Cazalla)

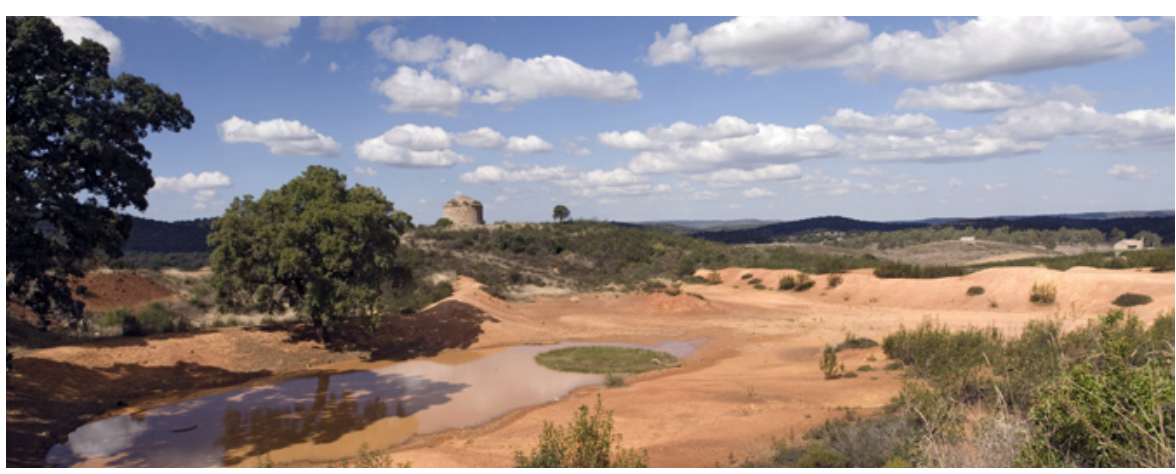

Paisaje megalítico del Valle del río Gor (Granada) foto Fondo Gráfico IAPH (Juan Carlos Cazalla)

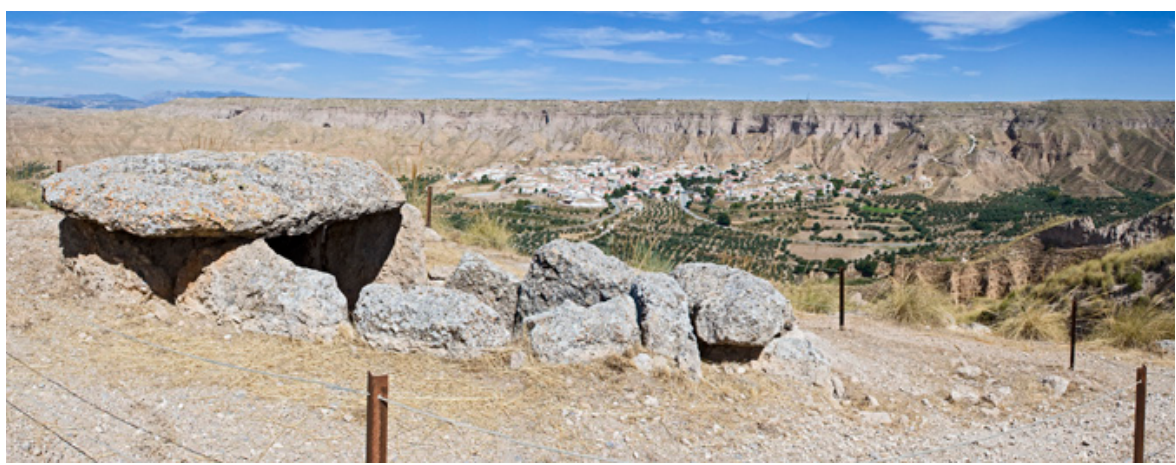

Paisaje molinero del Río Tinto (Huelva) | foto Fondo Gráfico IAPH (José María Rodrigo)

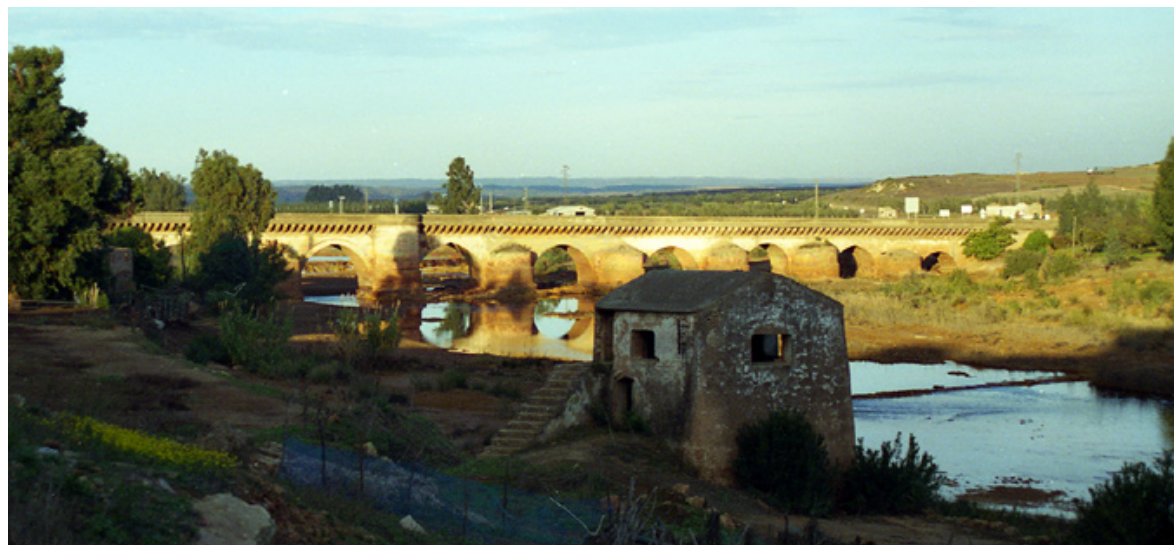


que los hacen manifiestamente mejorables. Entre los primeros destacan la riqueza y abundancia de recursos agrícolas y/o forestales, elementos físicos y arquitectónicos, fiestas y eventos singulares, mientras entre los segundos suelen aludir al mal estado de conservación de inmuebles, aldeas o pueblos y el atraso en las economías locales. También es muy habitual en este perfil la localización de lugares estratégicos en el paisaje, a modo de miradores, desde donde poder describir y/o dibujar perspectivas singulares en diferentes paisajes. Sus discursos y dibujos suelen incluir los accesos a ciudades o pueblos, la existencia de grandes y productivas zonas de cultivo, lugares de paso, y las relaciones entre núcleos urbanos.

Los periodistas se caracterizan por un discurso sintético que suele poner el acento sobre un aspecto concreto del paisaje que generalmente es objeto de la disección periodística con el objetivo de difundirlo o bien contribuir a su descubrimiento y puesta en valor. En su discurso, los diferentes valores patrimoniales del paisaje se hacen visibles a través de la gastronomía (un plato típico, los productos de la huerta, los dulces tradicionales), las fiestas, ciertos elementos naturales (cuevas, valles, montañas), los inmuebles de gran entidad (iglesias, palacios..), la singularidad de las arquitecturas tradicionales y costumbres "curiosas" o "atípicas", pero siempre "tradicionales y ancladas en el pasado" a ojos del periodista. Esto se puede constatar, por ejemplo, en el Valle de Lecrín, en lo recogido por un periódico local donde las acequias son las protagonistas (ORTEGA MARTíN, 2010: 3).

El mundo digital, finalmente, abre unas enormes posibilidades en las imágenes mostradas que incluye la denuncia de activistas sobre el estado de conservación de ciertos paisajes o elementos integrantes de ellos -como es el caso de Pegalajar-, el desarrollo de actividades económicas, lúdicas y festivas, o su potencialidad o excepcionales cualidades para su configuración como destino turístico y la práctica del deporte activo.

\section{UN REGISTRO PARA LA ACCIÓN TERRITORIAL. DE LA DOCUMENTACIÓN A LA REDACCIÓN DE RECOMENDACIONES PAISAJÍSTICAS}

La vocación de cualquier trabajo científico es convertirse en un instrumento para la acción y la conformación de criterios; en la generación de propuestas y orientaciones; en la previsión de posibles disfuncionalidades y en el enriquecimiento del acerbo intelectual con las aportaciones realizadas y con la implementación práctica de los contenidos científicos trabajados.

En el R-PICA, el método planteado posee aspectos claramente innovadores, aunque también importantes retos ante un marco normativo y político-administrativo muy inmaduro en materia de paisajes de interés cultural. No obs- 
tante, no se ha eludido la elaboración de unas líneas básicas para orientar la salvaguarda y activación. Esto se realizó en un apartado específico y sintético de "Valoración, diagnóstico y recomendaciones" referido a cada paisaje. En otras palabras, al final de cada ficha de registro, se destilaron los valores paisajísticos de cada paisaje, se identificaron los principales impactos y amenazas que les afectan y se propusieron una serie de recomendaciones para el mantenimiento de los valores paisajísticos (naturales y culturales) identificados.

Las recomendaciones no se organizan según un esquema rígido, sino, al contrario, apuntan a aspectos clave sin tener que presentar una relación completa con el cuadro administrativo general de una comunidad autónoma como Andalucía. Ahora bien, los aspectos que más se repiten tienen que ver:

a) Con las condiciones de visibilidad e intervisibilidad de los paisajes de interés cultural.

b) Con aspectos que vienen determinados por su infraestructura físico-natural; fundamentalmente respecto a dinámicas que afectan al protagonismo del relieve, agua, vegetación, etcétera.

c) Con cuestiones que pueden alterar la lectura de la construcción histórica del territorio; aquí se incluyen las políticas agrarias, las urbanístico-territoriales, las de transportes, etcétera.

d) Con los atributos inmateriales del paisaje, especialmente con los vínculos que los asocian a símbolos, ideas y creencias, y que condicionan las percepciones. En este último caso las recomendaciones se vinculan a aspectos relacionados con la educación o la sensibilidad social.

Se es consciente de que estas valoraciones-diagnóstico-recomendaciones son un primer paso para abrirse a las poblaciones locales e incorporar sus aspiraciones. En todo caso, el verdadero sentir de este trabajo, además de proporcionar algunas claves básicas para las políticas públicas, es plantear el necesario traslado de información de las instancias administrativas a los verdaderos protagonistas de los paisajes culturales: las personas que los han creado, los han mantenido, los viven y entienden.

Información para la acción, pero también para la reflexión y para que quienes habitan estos paisajes puedan, junto a otras informaciones y planes que proyecten la línea que abre este Registro, optar por modelos de desarrollo que aumenten su autoestima y les hagan ganar calidad de vida al tiempo que conservan y mejoran sus paisajes. 


\section{BIBLIOGRAFÍA}

- Atlas de Andalucía, Tomo II, Cartografía ecológica y territorial. Escala 1:400.000 (2005) Sevilla: Consejería de Obras Públicas y Transportes, Consejería de Medio Ambiente, 2005

- caballero SÁNChEZ, J. V.; DURÁN SALAdo, I.; GARCíA VÁZQUEZ, I. et ál. (2011) El paisaje en el Conjunto Arqueológico Dólmenes de Antequera. Sevilla: Instituto Andaluz del Patrimonio Histórico (PH Cuadernos; n. ${ }^{\circ}$ 28)

- DECRETO 206/2006, de 28 de noviembre de 2006 por el que se adapta el Plan de Ordenación del Territorio de Andalucía a las Resoluciones aprobadas por el Parlamento de Andalucía en sesión celebrada los días 25 y 26 de octubre de 2006 y se acuerda su publicación. Boletín Oficial de la Junta de Andalucía, n. ${ }^{\circ} 250$ de 29 de diciembre de 2006, pp. $14-15$

- DIRECTRICES Prácticas para la aplicación de la Convención del Patrimonio Mundial. (2008) [en línea] WHC. 08/01. Enero 2008. UNESCO. <http://whc.unesco. org/archive/opguide08-es.pdf> [Consulta: 15/06/2015]

- DURÁN SALADO, M. I. (2012) Megalitismo y ciudadanía en Antequera (Málaga): aproximación a los usos y significados sociales como estrategia para la gestión sostenible. Revista Menga, n. ${ }^{\circ}$ 3, 2012, pp. 223-230

- FERNÁNDEZ CACHO, S.; FERNÁNDEZ SALINAS, V.; HERNÁNDEZ LEÓN, E. et ál. (2010) Paisaje y Patrimonio Cultural en Andalucía. Tiempo, Usos e Imágenes. 2 vol. Sevilla: Instituto Andaluz del Patrimonio Histórico, Consejería de Cultura (PH Cuadernos; $n .^{\circ} 27$ )

- FERNÁNDEZ SALINAS, V. (2013) Los paisajes de interés cultural de Asturias. Ería, 91, 12013, pp. 129-149

- LEY 14/2007, de 26 de noviembre, del Patrimonio Histórico de Andalucía. Boletín Oficial de la Junta de Andalucía, n. ${ }^{\circ}$ 248, de 19 de diciembre de 2007

- ORTEGA MARTíN, E. M. (2010) Acequias, el mirador de Lecrín. El Valle de Lecrín [recurso disponible en línea], diciembre 2010, p. 3 <http://adurcal.com/mancomunidad/ guia/lecrin/acequias/periodico_12_10_acequias.pdf $>$ [Consulta: 28/07/2015]

- PLAN Nacional de Paisaje Cultural (2012) (en línea) Madrid: Instituto del Patrimonio Cultural de España, Ministerio de Educación, Cultura y Deporte. <http://ipce. mcu.es/pdfs/PLAN_NACIONAL_PAISAJE_CULTURAL. pdf> [Consulta: 15/06/2015]

- QUINTERO MORÓN, V.; HERNÁNDEZ LEÓN, E. (2012) Paisajes patrimoniales y percepciones locales. En XVII Congreso de Estudios Vascos: Gizarte aurrerapen iraunkorrerako berrikuntza = Innovación para el progreso social sostenible (17. 2009. Vitoria-Gasteiz). Donostia-San Sebastián: Eusko Ikaskuntza, 2012, pp. 627-647.

- RODRIGO CÁMARA, J. M; DÍAZ IGLESIAS, J. M.; FERNÁNDEZ CACHO, S. et ál. (2012) Registro de paisajes de interés cultural de Andalucía. Criterios y metodología. Revista ph (recurso disponible en línea), n. ${ }^{\circ} 81,2012$, pp. 64-75 <http://www.iaph.es/revistaph/index.php/revistaph/ article/view/3280> [Consulta: 23/07/15] 